\title{
O-129人間ドックの前立腺検診における癌診断率及ひ年齢別血清PSA 值
}

帯広厚生病院

田端哲也、駒木 亨、大山 格、高橋和明、坂下茂夫

1 年間 (1994 年 4 月 1995 年 3 月) の当院入間ドックの前立腺检梌受梌者の前立腺癌診断率及び年噛別PS A值の 变動を検討した。く対象〉人間ドック受誩者のうち50歳以上で、前立腺癌検診希望者 1223 例。平均年齢 56 才 (50オ 80才)。<方法>経直腸的前立腺触診 (以下DRE) および血清PSA（IMX法）を測定した。いずれか 亿異常を認めた症例に対し後日、泌尿器科外来でDRE、PSAを再検し、再で異常を認めた症例に経直腸的 エ コー（アロカ社SSD 2000、エンドファイヤープローベ、Biopty Gun）下の sys tematic 経直腸的前立湶針生検施 行。<結果>検診時飞 127 例 (10.4\%) 亿異常 (DRE 異常 87 例、PSA高值 46例)を認めた。うち 56 例 (44.1 \%) 亿再び癌を疑い経直腸的前立腺生検を施行。6例が組織学的に前立腺滀之晾断され、前立腺検診受晾者の 0.49\%、生検施行者の $12.5 \%$ が癌と彮断されたととになる。6例の患者の臨床病期はいずれもC、次下で PSA 値の平均値は $34.0 \mathrm{ng} / \mathrm{ml}(4.4 \sim 124.8 \mathrm{ng} / \mathrm{ml})$ であった。うち5例で前立腺全摘術を施行し、術後病期はB 1例、C 4例であった。前立腺検診を受けた癌以外の男性の年齢別PSA值 (age specific reference range、以下 ASRR) は、 $50 \sim 54$ 才で $1.0 \mathrm{ng} / \mathrm{ml} 、 55 \sim 59$ 才で $1.2 \mathrm{ng} / \mathrm{ml} 、 60 \sim 64$ 才で $1.3 \mathrm{ng} / \mathrm{ml} 、 65 \sim 69$ 才で 1.7 $\mathrm{ng} / \mathrm{ml} 、 70 \sim 74$ オで $1.8 \mathrm{ng} / \mathrm{ml}$ と年齢との相関か認められた。<考案>前立腺癌検診 (DRE、F'SA測定) は 手術適応の癌の発見に有用であるが、今回見つかった癌は早期癌とは言い難加った。今回の検討では、50才か ら74才までの年龄では、ASRRが年齢との間に相関を認め、PSA值は年齢別に正常値を設定できると考え られた。

$0-130$

検款でのPSA 测定に関する検体保存条件、测定方法の娭时

同愛記念病院 泌尿器科 ${ }^{1)}$ 、同検查科 ${ }^{21}$ 、侏式会社 SRL

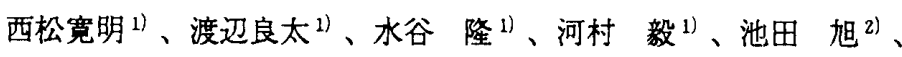

手島伸一2)

目的：墨田区老人健康診査に平成七年度から、前立腺癌検診が追加となった。建診は様々な施設で笑施されてい ることから、採血後の検体管理に関して全施設で実施可能な検体保存条件を設定する必要が生しただ、我々は すみだ瘦検診部会（畦田三医師会）から依頼を受け検体保存条件、測定方法に関する検討を行った。方法：前立 腺癌症例 10 例、BPH 症例 5 例に関して AXSYM (IMX) 法によるPSA, PAP と Tandem- $\mathrm{R}^{\star}$ 法によるPSA 朋い全血保存、 血清に分離後保存、室温保存、 $4^{\circ} \mathrm{C}$ 保存、の条件を組み合わせ、経過時間での変化（0〜72時間まで 4 〜 8 ポイト) を検討した。また最も現状に即した全血、室温 $\left(28^{\circ} \mathrm{C}\right)$ の保存状態での経時的変化(0〜48時間まで 3 ポイント)に ついて、前立腺癌疑いで当科を受診した 50 例に関してTandem・R法によるPSAを用いて追加検討した。結果:PSA の保存による安定性は、72 時間までは全血または血清を冷蔵庫、室温のどちらの条件でも安定であった(平均変 化率：5.3\%)。PAPは全血を室温保存すると、測定值は低瀑度では時間と共に上年し、高港度域で汁安定だった。 また血清分離後室温保存した場合は逆に著しく低下した。しかし冷葴庫保存だと 24 時間までは安㞣であった。

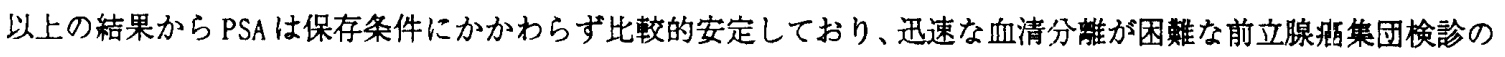
スクリーニングに有用な測定方法と思われた。また今後の墨田区での前立腺癌検診に関して、診断効率上昇の試 みとしてCortez社の隔易PSA 测定キット(One-Step Serum PSA Test)に着目し,その Mass screeningへの適合の 可否を検討するため 150 例程度での preliminary studyを行っており、当日はその結果も含めて報告する。 